\title{
PENINGKATAN KUALITAS PAKAN, TEKNIK PERAWATAN DAN MANAJEMEN USAHA PETERNAKAN KAMBING PE DI DESA MOROWUDI KECAMATAN CERME KABUPATEN GRESIK
}

\author{
Wardah $^{1 *}$, Hari Poernomo ${ }^{2}$ \\ 1,2 Fakultas Ekonomi Pembangunan Universitas 17 Agustus 1945 Jl. Semolowaru 45, Surabaya \\ *Penulis korespondensi; email: wardahassery@yahoo.co.id
}

\begin{abstract}
Abstrak: Keberhasilan wirausaha peternakan kambing Etawah adalah pemilihan bibit, pemberian pakan berkualitas dan manajemen kesehatan ternak. Hasil samping pengelolaan susu dan kotoran dapat meningkatkan nilai ekonomis. PKM ini bertujuan membantu peternak mitra (Bapak Solikan) di Desa Morowudi, Cerme, Gresik yang memiliki 214 ekor kambing Etawah. Masalah yang dihadapi mitra adalah: Ketersediaan pakan berkualitas terutama saat kemarau, tingkat mortalitas anak dan induk kambing tinggi, pengetahuan pengelolaan susu dan feses, manajemen wirausaha dan pemasaran belum dikuasai. Keterbatasan pengetahuan peternak menyebabkan masalah tidak terselesaikan dengan baik. Metode pelaksanaan kegiatan berupa pelatihan pembuatan pakan berkualitas dan murah, penanganan induk dan anak pasca kelahiran, teknik pengelolaan susu dan feses, serta manajemen asset dan pemasaran. Hasil pengabdian ini dapat meningkatkan pengetahuan peternak menyediakan pakan yang difermentasi dengan MC-4, mudah dan murah dengan kualitas lebih baik, palabilitas tinggi, daya simpan pakan lebih lama dibanding pakan sebelumnya yang mencampur hijauan/jerami dengan ampas tahu, difermentasi 4 jam sehingga cepat busuk karena basah sehingga mudah busuk dan menyebabkan ternak kembung apabila tidak segera dikonsumsi. Hasil pelatihan penanganan induk dan anak pasca kelahiran, pengelolaan susu dan feses, serta manajemen asset dan pemasaran dapat dimengerti dengan baik dan mudah oleh peternak mitra sehingga dalam jangka panjang akan menekan mortalitas anak dan induk.
\end{abstract}

Kata kunci: Ternak; Etawah; pakan; perawatan; wirausaha.

\begin{abstract}
The success of Etawah goat farming bussines influenced by the selection of broodstock, feeding and livestock health management. The aims ofpeople service programe (PKM) to help partner of go at farmers (Mr. Solikan) in Morowudi Village, Cerme, Gresik who have 214 heads of Etawahgoats. The Unavailability of high quality of fodder forage especially during dry season, and high mortality of lamb and adult goat female are major problem that faced by partners goat farmer. In addition, partner goat farmer also have problems in milk and feces processing techniques, bussines management and marketing of livestock products. The limited knowledge and skill of fermentation and feed technology, bussines management and marketing techniques have caused these problems not resolved by the partner farmers. The method of carrying outactivities in the form of training in making quality and inexpensive feed, handling mother and child after birth, milk and feces management technique, and asset management and marketing. The result of this service can increase the knowledge of breeders providing fermented feed with $M C-4$, easy and inexpensive with better quality, high palability, longer shelf life of feed compared to previous feeds that mix forage/straw with tofu pulp, fermented 4 hours so that it decays quickly because it is wet soit easily rot and cause cattle to bloat if not consumed immediately. The results of training in handling post-natal mother and child, management of milk and feces, as well as asset management and marketing can be understood well and easily by partner farmers so that in the long run it will reduce the mortality of children and motherllmu.
\end{abstract}

Keywords: Livestock; Etawah; feeding; handling; enterpreneur.

\section{PENDAHULUAN}

Usaha peternakan kambing sudah berkembang cukup pesat, seiring dengan laju perkembangan penduduk. Kambing merupakan hewan ruminansia yang sudah sangat lama menjadi hewan piaraan yang berasal dari daerah Asia Barat dan Persia. Banyak jenis kambing sesuai dengan daerah asalnya seperti Etawah dari Jamnapari India, kambing Apin dari pegunungan Alpen di Swiss, kambing Saanen dari Swiss, kambing Anglo Nubian dari Nubian timur laut 
Afrika, kambing Beetel dari Rawalpindi dan Lahore, Pakistan serta di Punjab, India.

Di Indonesia, usaha peternakan kambing sudah dikenal sejak dahulu kala, tetapi pengetahuan tentang pembudidayaan secara intensif dan teknik perawatan serta manajemen usaha ternak kambing masih sering menjadi persoalan bagi peternak. Kambing asli Indonesia seperti kambing Kacang, kambing Samosir dan kambing Marica memberikan petunjuk bahwa penduduk Indonesia telah mengenal peternakan kambing sudah cukup lama untuk diambil dagingnya atau untuk sebuah usaha. Salah satu upaya pengembangan ternak kambing yang sudah berjalan adalah pekawinan silang antara jenis kambing Etawah dengan kambing lokal/kambing Kacang yang menghasilkan jenis kambing Peranakan Etawah (PE) atau sering dikenal sebagai kambing PE. Kambing PE berukuran hampir sama dengan Etawah namun lebih adaptif terhadap lingkungan lokal Indonesia.

Pejantan kambing PE memiliki sex-libido yang tinggi, dan memiliki ciri-ciri sebagai berikut:

1. Warna bulu belang hitam, putih, merah, coklat dan kadang putih;

2. Badannya besar sebagaimana kambing Etawah, bobot yang jantan bisa mencapai $91 \mathrm{~kg}$, sedangkan betina mencapai $63 \mathrm{~kg}$;

3. Telinganya panjang dan terkulai ke bawah, bergelambir yang cukup besar;

4. Dahi dan hidungnya cembung;

5. Kambing jantan maupun betina bertanduk kecil/pendek;

6. Daerah belakang paha, ekor dan dagu berbulu panjang;

7. Kambing Peranakan Etawah mampu menghasilkan susu hingga tiga liter per hari.

Sentra pengembangan kambing PE banyak terdapat di sekitar daerah Jogyakarta seperti di Bantul, Sleman, Gunung Kidul dan Kulon Progo. Di Jawa Timur terdapat di Tulungagung, Blitar, dan Malang, sedang di Jawa Tengah banyak terdapat di Pati, Banyumas, Banjarnegara, Kebumen, Wonosobo dan Jepara. Di Jawa Barat ada di Bogor, Bandung dan Sukabumi, serta Palembang dan Lampung. Namun saat ini sudah menyebar hampir di seluruh pulau Jawa dan beberapa kota/ kabupaten di Sumatra. Penyebaran kambing jenis $\mathrm{PE}$ ini dilandasi dengan kebutuhan terhadap susu kambing untuk pengobatan, digunakan sebagai pejantan untuk memperbaiki kualitas kambing lokal pedaging, dan sebagai kambing hias atau kontes yang memiliki nilai jual tinggi. Di Kabupaten Gresik sendiri populasi ternak rumunansia mencapai sapi 52.600 ekor, Kambing 55.000 ekor dan Domba 30.000 ekor.

Morowudi, adalah sebuah desa di Kecamatan Cerme Kabupaten Gresik berjarak $13 \mathrm{Km}$ dari
Kota Gresik. Desa ini terkenal dengan industri rumahan yang memprduksi makanan ringan (camilan). Industri makanan ringan ini diproduksi oleh sebagian besar warga Dusun Ngebret seperti jagung, kacang beras, usus ayam, kedelai, kacang, keripik pisang, keripik singkong, ketela, makaroni, kacang tanah dan gadung.

Berdasarkan letak geografis, Desa Morowudi berada di dua pertemuan sungai yaitu di sebelah utara desa terdapat Sungai Medangan sedangkan di sebelah selatan desa terdapat sungai Lamong. Kedua sungai ini bermuara ke Laut Jawa namun sebelum sampai ke laut kedua sungai ini bertemu dalam satu titik pertemuan yaitu di Desa Morowudi. Daerah ini tergolong subur baik untuk pertanian maupun untuk perikanan darat. Usaha ternak ruminansia terutama penggemukan kambing dan produksi susu kambing Peranakan Etawah (PE) mempunyai nilai ekonomis yang sangat penting bagi peternak di Desa Morowudi Kecamatan Cerme, Gresik. Di desa ini terdapat sekitar lima peternak dan yang terbesar adalah peternakan kambing milik Bapak Solikan. Peternak mitra mempunyai usaha peternakan ruminansia khusus kambing PE sebagai mata pencaharian utama, di samping usaha lain berupa makanan camilan yang sudah digeluti sejak 10 tahun terakhir. Seiring dengan berbagai permasalahan pada bisnis makanan camilan, usaha peternakan kambing akhir-akhir ini justru menjadi andalan peternak mitra di Desa Morowudi, karena secara signifikan dapat meningkatkan pendapatan keluarga.

Bapak Solikan yang mengawali ide memelihara kambing PE awalnya di tahun 2007 sejumlah 4 ekor betina dan 1 ekor pejantan dengan dana yang dikeluarkan sebesar Rp 10 juta. Saat ini (tahun 2019) kambingnya sudah mencapai 200 ekor. Peternak mitra (Bapak Solikan) dengan latar belakang pendidikan yang sangat terbatas belajar memelihara kambing secara otodidak, namun mampu mengembangkan populasi kambingnya melalui perputaran dana hasil ternak kambing.

Saat ini kendala yang sering dihadapi oleh peternak mitra adalah: masih rendahnya pertambahan bobot badan harian. Di samping masih rendahnya pengetahuan perawatan kambing Peranakan Etawah, kesehatan kambing dan produksi susu serta manajemen usaha yang baik. Selain itu beberapa masalah lain yang dihadapi diantaranya seperti masalah kandang, keterbatasan bahan pakan, proses pengolahan pakan, tingkat mortalitas yang tinggi pada anak kambing, pemasaran dan perputaran dana pemeliharaan serta manajemen usaha ternak. Problema ini dihadapi sendiri tanpa ada pendampingan baik dari pemerintahan Kabupaten Gresik maupun dari pihak perguruan tinggi. Oleh karenanya, program PKM ini dipilih dan dilaksanakan untuk mendampingi Bapak 
Solikan dalam berwirausaha di bidang peternakan kambing Peranakan Etawah (PE). Beberapa gambaran mengenai kondisi lingkungan ternak mitra disajikan pada beberapa gambaran sebagai berikut.

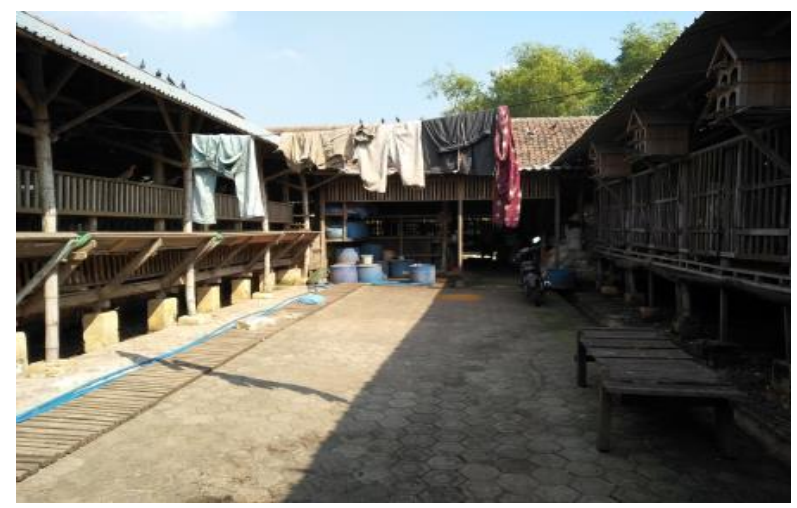

Gambar 1. Lingkungan Usaha Peternakan Bapak Solikan (Sumber: Dokumentasi Kegiatan PKM 2019)

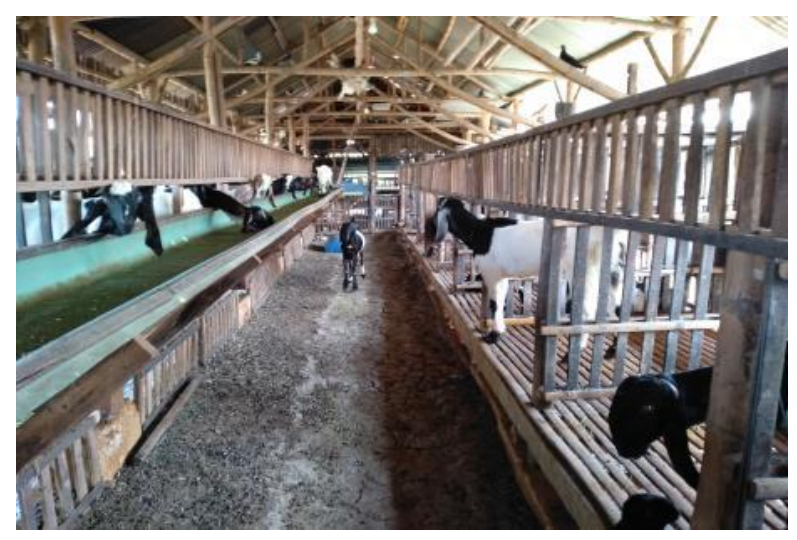

Gambar 2. Kandang Indukan yang baru melahirkan (Sumber: Dokumentasi Kegiatan PKM 2019)

\section{Permasalahan Mitra}

Bagi seorang peternak otodidak dengan latar belakang pendidikan yang sangat terbatas, Problema yang dihadapi Bapak Solikan adalah:

1. Biaya pakan yang diproduksi Bpk Solikan relatif mahal.

2. Pengadaan bahan pakan berupa ampas tahu harus disediakan setiap hari

3. Pembuatan pakan harus dilakukan dua kali setiap hari.

4. Saat musim kering sangat kesulitan mendapatkan bahan pakan.

5. Tingkat kematian (mortalitas) anak dan induk kambing relatif tinggi

6. Hasil samping berupa susu dan kotoran kambing belum dimanfaatkan secara optimal.

7. Manajemen asset ternak dan pemasaran belum dikuasai.

Dengan segala keterbatasannya, Bapak Solikan tidak memiliki akses pembinaan, pendampingan dan pelatihan serta konsultasi sehingga program ini bagai gayung bersambut antara program pengabdian masyarakat perguruan tinggi dengan problema yang dihadapi masyarakat. Melalui program kemitraan masyarakat (PKM), program pelatihan dan pendampingan dapat terwujud. Tujuan dari program PKM ini adalah Mitra peternak mampu membuat dan menyediakan pakan yang cukup secara mandiri dan strategi pemeliharaan kambing Etawah merupakan persoalan prioritas.

Pemberian pakan hijauan dan konsentrat sangat besar peranannya dalam meningkatkan pertambahan berat badan maupun produksi susu. Peningkatan daya cerna pakan konsentrat dalam usaha meningkatan pertambahan bobot badan harian dapat dilakukan dengan melakukan fermentasi pakan konsentrat probiotik. Namun demikian, keterbatasan pengetahuan penyusunan ransum dan peningkatan nutrisi pakan merupakan kendala utama yang dihadapi peternak mitra, terutama pemanfaatan bahan baku lokal untuk produksi konsentrat. Fluktuasi ketersediaan pakan hijauan untuk ternak kambing Etawah juga merupakan permasalahan yang dihadapi peternak. Hijauan pakan ternak khususnya rumput dan leguminosa tersedia secara melimpah pada saat musim penghujan, namun ketersediaan hijauan pada musim kemarau sangat terbatas.

Pengetahuan pengawetan hijauan merupakan masalah yang dihadapi peternak kambing Etawah dalam menyediakan hijauan pakan secara kontinyu, khususnya pada musim kemarau. Potensi fisik jerami padi dan jagung yang melimpah di desa ini belum sepenuhnya dimanfaatkan oleh petani setempat, bahkan hanya sekitar $20 \%$ saja yang digunakan sebagai pakan ternak. Kendala utama penggunaan jerami sebagai pakan ternak adalah kecernaan jerami yang hanya sekitar $40 \%$, serta kandungan proteinnya hanya sekitar $3-5 \%$, di samping palatabilitasnya yang rendah. Rendahnya nutrisi, kecernaan dan palatabilitas selanjutnya berdampak pada bobot badan dan produksi susu kambing Peranakan Etawah.

Peningkatan nilai nutrisi dan daya cerna limbah pertanian dapat dilakukan dengan proses fermentasi limbah pertanian. Keterbatasan pengetahuan teknologi produksi konsentrat serta fermentasi limbah pertanian untuk menghasilkan pakan terfermentasi juga merupakan persoalan yang dihadapi peternak mitra di desa Morowudi. Manajemen usaha pemeliharaan kambing Etawa sangat rendah terutama dalam pencatatan data populasi dan kontrol kesehatan ternak, perawatan ternak pasca melahirkan dan pemeliharaan anak kambing serta analisis usaha dan pemasaran hasil ternak yang tepat juga menjadi persoalan prioritas yang dihadapi Bapak Solikan. 


\section{Target dan Luaran}

Target utama kegiatan ini adalah memberikan pelatihan dan pendampingan terhadap Bapak Solikan di Desa Morowudi Kecamatan Cerme Kabupaten Gresik. Adapun luaran kegiatan ini adalah:

1. Peternak mitra mampu membuat dan menyediaan pakan formulasi dengan teknologi konsentrat probiotik dan fermentasi jerami dengan bahan baku dari limbah pertanian yang lebih murah dan memiliki palatabilitas tinggi.

2. Mampu menangani sistem pemeliharaan dan perawatan kesehatan ternak terutama induk dan anak kambing yang baru dilahirkan.

3. Pendampingan teknis manajemen wirausaha penggemukan kambing dan susu serta pemasaran kambing Peranakan Etawah.

\section{METODE PELAKSANAAN}

Metode pelaksanaan atau tahapan yang dilakukan dalam program pengabdian masyarakat ini ditunjukkan pada Gambar 3.

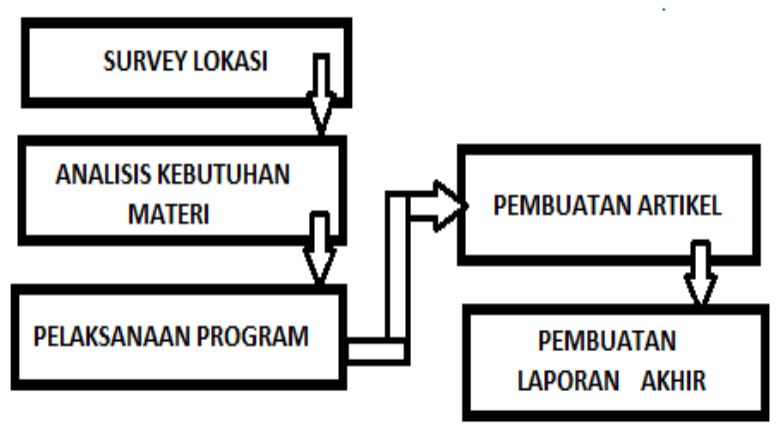

Gambar 3. Metode Pelaksanaan (Sumber: Dokumentasi Kegiatan PKM 2019)

Beberapa tahapan metode pelaksanaan pengabdian kepada masyarakat dilaksanakan sebagai berikut, yaitu:

1. Survey Lokasi Obyek Pengabdian Kepada Masyarakat

2. Analisis Kebutuhan Materi

3. Pelaksanaan Kegiatan

4. Manajemen pencatatan ternak

5. Pelatihan Pembuatan Pakan Kambing

Tabel 1. Prioritas problema Peternak Mitra

\begin{tabular}{ll}
\hline No & Persoalan \\
\hline $1 . \quad \begin{array}{l}\text { Kemampuan membuat dan ketersediaan pakan } \\
\text { alternatif yang lebih murah dan palatabilitas tinggi }\end{array}$ \\
2. $\quad \begin{array}{l}\text { Sistem pemeliharaan ternak, peningkatan produksi } \\
\text { susu dan kesehatan ternak belum tertangani }\end{array}$ \\
$\begin{array}{l}\text { dengan baik. } \\
\text { 3. Teknis usaha penggemukan }\end{array}$ \\
4. $\quad$ Pengolahan dan Pemasaran susu kambing \\
\hline Sumber: Dokumentasi Kegiatan PKM 2019
\end{tabular}

\section{HASIL DAN PEMBAHASAN}

Pengabdi telah melakukan survey ke Desa Morowudi terlebih dahulu untuk mensurvey peternak kambing Etawa dan menganalisis kemungkinan pelaksanaan progam PKM di daerah tersebut. Berdasarkan hasil survei diperoleh keputusan bahwa Bapak Solikan adalah salah satu peternak yang memiliki sebanyak 214 ekor kambing peranakan Etawah (PE) dan berpotensi untuk menjadi Peternak Mitra pada program PKM ini. Dilanjutkan dengan diskusi mendalam tentang problema yang dihadapi selama berwirausaha beternak kambing Etawa. Dari hasil diskusi ditemukan beberapa yang menjadi prioritas masalah dalam program PKM ini.

\section{Analisis Kebutuhan Materi}

Dari hasil penentuan prioritas problema peternak mitra, dilakukan analisis kebutuhan materi diantaranya adalah:

a. Bahan hijauan pakan yang berasal dari limbah pertanian disekitar desa seperti jerami padi, batang pohon jagung dan alang-alang, dedak mineral, tetes dan media biakan MC4 untuk kebutuhan praktek pembuatan pakan probiotik.

b. Tenaga ahli bidang peternakan (dokter hewan) dalam rangka pelatihan perawatan kesehatan ternak.

c. Analisis laboratorium formula pakan probiotik sebelum dan sesudah pelatihan.

\section{Pelaksanaan Kegiatan}

Dimulai dari diskusi mendalam di lokasi peternakan milik Bapak Solikan tentang apa yang sudah dikerjakan oleh peternak mitra berkaitan dengan prioritas masalah dan apa yang belum dikerjakan oleh mitra peternak. Dari hasil diskusi diperoleh informasi sebagai berikut:

1) Selama ini peternak mitra menghabiskan bahan tambahan untuk pembuatan pakan berupa ampas tahu hingga mencapai $500 \mathrm{~kg} / \mathrm{hari}$ untuk campuran hijauan rumput (legumenisa), tetes, kulit dan bonggol ketela pohon ditambah dengan media pembiakan EM-4.

2) Pembuatan pakan dibuat sehari dua kali pagi dan siang melalui proses fermentasi selama 4 jam kemudian diberikan kepada ternak.

3) Untuk perlakuan induk yang beranak selalu mengalami pembengkaan pada ambing dan anak kambing susah menyusu pada induknya. Beberapa hari kemudian anak mengalami kematian dan sering disusul kematiab induknya.

4) Masalah susu yang dihasilkan oleh kambing ini sama sekali belum disentuh secara ekonomis. Ketidaktahuan cara proses pemerahan yang benar dan higienis serta pasar yang membutuhkan menjadi persoalan tersendiri. 
Manajemen pencatatan ternak juga belum tertangani secara baik, sehingga sangat mungkin terjadi perkawinan satu gen diantara ternak (inbreeding) dan mengakibatkan kerawanan terhadap kesehatan ternak.

Saat kegiatan pelatihan telah dilakukan pengecekan induk yang baru beranak dengan kondisi susu yang membengkak dan anaknya kesulitan menyusui. Hal ini diduga ada beberapa faktor penyebab kondisi induk setelah beranak, antara lain karena faktor inbreeding, jenis dan kualitas pakan, serta penanganan proses kelahiran yang kurang sempurna. Untuk penanganan- nya dilakukan penyekaan dengan air hangat pada ambing susu induk dan anak kambing dibantu menyusu dari alat botol-dot. Hasilnya sangat baik, yaitu susunya tidak bengkak dan dapat diperah serta anak kambing dapat menyusu secara rutin.

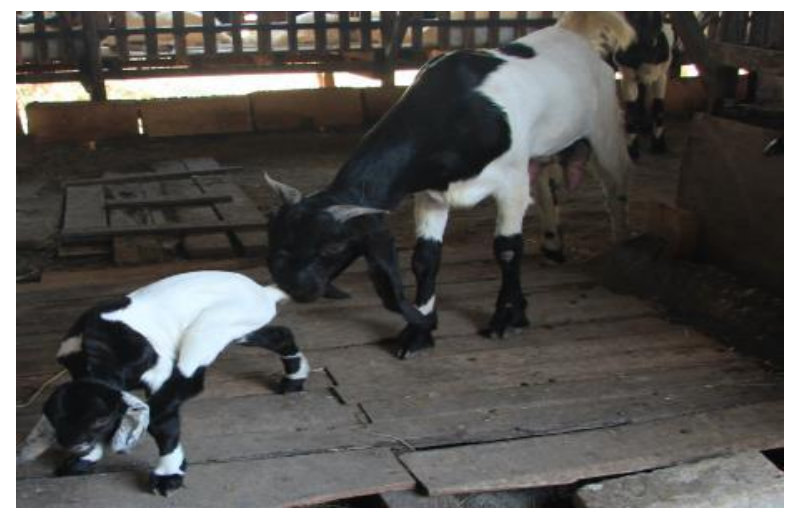

Gambar 4. Susu Induk Bengkak dan anak enggan menyusui (Sumber: Dokumentasi Kegiatan PKM 2019)

Pelatihan selanjutnya adalah pembuatan pakan alternatif yang lebih efektif dan lebih murah dengan bahan hijauan, dedak, tetes dan mineral yang difermentasi dengan media MC4. Pelatihan ini sekaligus praktek langsung mulai dari chopper hijauan/jerami dan pencampuran bahan fermentasi dengan MC4.

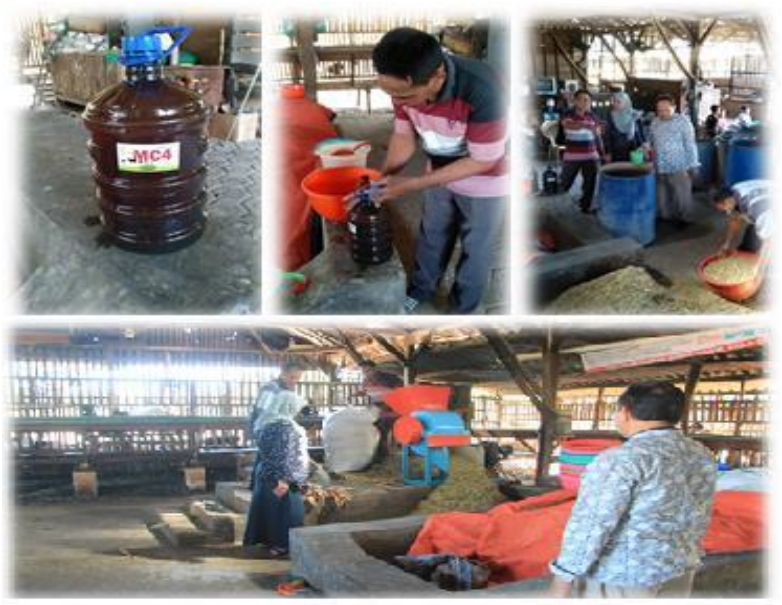

Gambar 5. Proses pelatihan pembuatan Pakan (Sumber: Dokumentasi Kegiatan PKM 2019)
Pelatihan pembuatan pakan tidak hanya pemberian contoh, tetapi sekaligus juga dilaksanakan sendiri oleh peternak mitra. Pakan buatan dengan metode fermentasi ini memerlukan waktu 3-4 hari untuk siap dikonsumsi ternak dan masuk dalam kemasan drum plastik ukuran 100 liter dan ditutup rapat dengan plastik (kondisi anaerob). Untuk menghindari tekanan udara fermentasi, plastik harus dibuka setiap hari untuk membuang gas yang ditimbulkan dari hasil fermentasi.

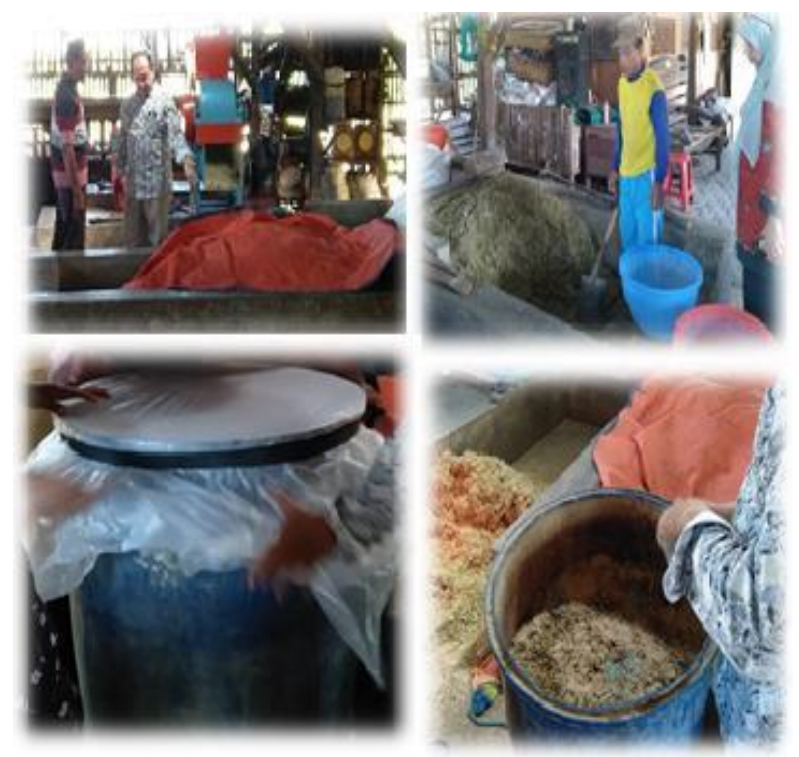

Gambar 6. Hasil pakan 4 jam fermentasi dengan EM4 (atas) dan hasil pakan 4 hari fermentasi dengan MC4 (bawah) (Sumber: Dokumentasi Kegiatan PKM 2019)

Dalam diskusi saat pembuatan pakan dengan MC4 didapatkan perhitungan biaya pakan yang jauh lebih sederhana dan lebih murah bahkan dapat menekan biaya pakan hingga $45 \%$ dari pada jenis pakan yang dibuat sebelumnya yang menggunakan ampas tahu dan difermentasi dengan EM4.

Dalam diskusi Manajemen wirausaha peternakan, diungkapkan perlunya pembuatan catatan usaha yang sederhana, misalkan jumlah ternak secara pasti, data umur ternak, jika perlu bobot ternak, tanda numerik ternak, catatan biaya bahan pakan sampai menjadi formula pakan serta hasil penjualan ternak. Selain itu karena penanganan hasil susu dan kotoran kambing belum ditangani secara serius, maka belum bisa dilakukan manajemen usaha dari pendapatan susu dan kotoran.

Hasil uji laboratorium terhadap komposisi nutrisi pakan hasil fermentasi dengan biakan EM4 sebagai pembanding dengan pakan hasil fermentasi yang menggunakan biakan MC4. Hasil uji laboratorium telah dilakukan terhadap sampel pakan yang menggunakan EM4 dengan hasil seperti pada gambar 7 . 


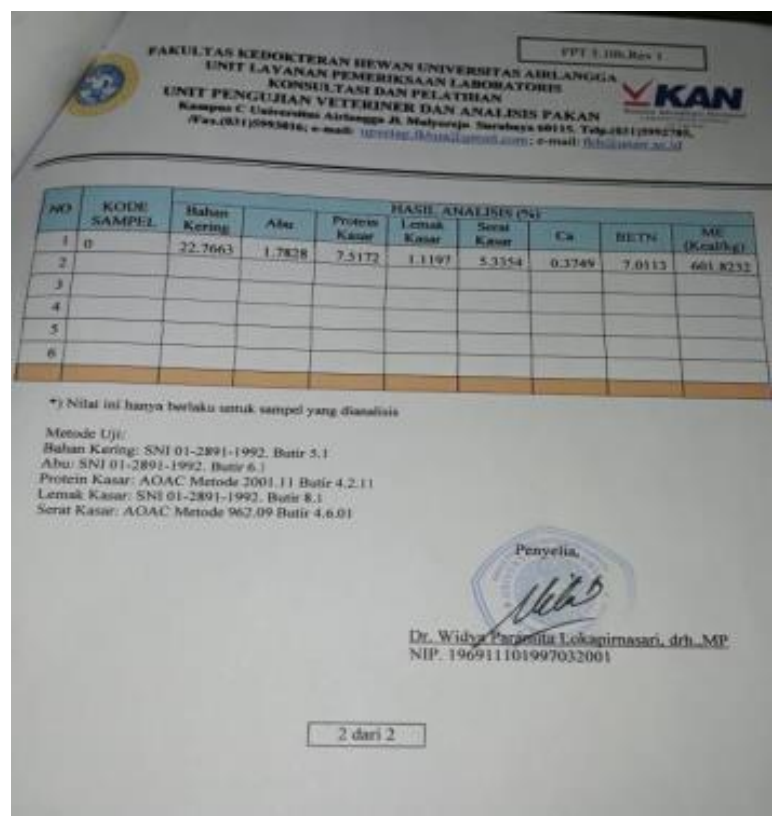

Gambar 7. Hasil Laboratorium Pakan Fermentasi dengan biakan EM4 (Sumber: Lab. Nutrisi Univ. Airlangga)

Untuk mengetahui peningkatan kualitas pakan, telah dilakukan uji laboratorium dengan biakan MC4. Namun secara nutrisi hasil laboratorium untuk pakan dengan biakan EM4 menunjukkan kurangnya kecukupan nutrisi yang dibutuhkan oleh ternak ruminansia baik untuk tujuan usaha pembibitan maupun untuk usaha penggemukan. Dengan demikian jika saat ini kondisi ternak yang ada terlihat gemuk dan sehat, maka ada pertanyaan mengapa tingkat mortalitasnya tinggi.

Tabel 2. Kebutuhan Nutrien Ternak Ruminansia

\begin{tabular}{lll}
\hline Kadar Nutrisi & Biakan EM4 & Biakan MC4 \\
\hline Kadar air & 12 & 9 \\
Bahan kering & 88 & 91 \\
Protein kasar & 10,4 & 12,7 \\
Lemak kasar & 2,6 & 3 \\
Serat kasar & 19,61 & 18,4 \\
Kadar abu & 6,8 & 8,7 \\
\hline
\end{tabular}

Sumber: Wahyono dan Hardiyanto (2004)

Pada tabel 2 menunjukkan bahwa kebutuhan nutrisi untuk ternak ruminansia baik untuk tujuan pembibitan maupun penggemukan sebagai pembanding hasil uji laboratorium pakan yang dibuat oleh peternak mitra.

\section{Pembuatan Pakan}

Peternak mitra memproduksi pakan dengan bahan-bahan hijauan yang dichopper dicampur dengan bekatul, ampas tahu, tetes, bonggol dan kulit ketela pohon selanjutnya di fermentasi dengan EM4 sebagai pembiakan bakteri. Teknik fermentasi yang diterapkan yaitu semi-aerob fermentation dengan menutupi bahan yang difermentasi menggunakan terpal. Pembuatan pakan ini dilakukan dua kali per hari pagi dan siang dengan masa fermentasi 4 jam, selanjutnya diberikan kepada ternak untuk dikonsumsi. Jika tidak segera diberikan, maka hasil pakan ini akan basi dan busuk. Secara fisik ternak sangat suka untuk memakan jenis pakan ini dan ternak terlihat sehat dan gemuk. Kendala pembuatan pakan jenis ini ada pada ketersediaan ampas tahu. Ampas tahu didapatkan dari desa sekitar di Kecamatan Cerme dengan kebutuhan sehari mencapai $500 \mathrm{~kg}$ setara dengan Rp. 500.000,- dan hanya dapat disimpan satu malam.

Pembuatan pakan probiotik dengan MC4 sebagai media biakan fermentasi dilakukan dengan proses chopper bahan hijauan/jerami selanjutnya ditambah bekatul sedikit, 2 sendok makan tetes yang telah dicampur air satu gayung ditambah 1sendok makan mineral dan langsung difermentasi dengan dua tutup galon media biakan MC4. Hasil campuran lalu dimasukkan dalam drum plastik berukuran 100 liter dan ditutup dengan plastik dan dibiarkan selama 3-4 hari selanjutnya di angin-anginkan sebentar dan dapat dikonsumsi oleh ternak. Metode ini disebut unaerob fermentation dengan harapan terjadi fermentasi yang sempurna.

Perbedaan pakan media biakan MC4 dengan pakan fermentasi yang dilakukan sebelumnya oleh peternak mitra terletak pada penggunaan ampas tahu dan bonggol kulit ketela pohon. Setelah mencapai 4 hari, pakan diujicobakan pada beberapa kambing mulai dari kambing anakan, dewasa, indukan bunting maupun yang baru melahirkan, ternyata meningkatkan palatabilitas pada ternak, terbukti pakan dimakan dengan lahap sebagaimana biasanya pakan sebelumnya. Pakan ini juga memiliki ketahanan dan keawetan lebih lama dibandingkan pakan sebelumnya karena pakan dalam keadaan kering. Berbeda dengan pakan sebelumnya yang basah sehingga cepat busuk, dapat menyebabkan ternak kembung apabila tidak segera dikonsumsi.

Untuk perawatan induk dan perlakuan anak kambing, telah diterapkan dengan melakukan penyekaan pada susu induk yang baru baru melahirkan dan membantu menyusukan melalui alat dot bayi untuk memastikan bahwa colostrum benar-benar masuk kedalam tubuh anak kambing yang baru dilahirkan. Di samping itu penanganan kelahiran harus benar dan higienis terutama perlakuan pada anak yang baru dilahirkan.

Untuk manajemen wirausaha peternakan sedang disusun model pencatatan sederhana dan mudah dikerjakan oleh peternak mitra, mulai dari data asal usul kambing, numerasi dan estimasi berat serta harga jual. Demikian pula dengan pen- 
catatan harga pokok pakan bagi seekor kambing per hari. Khusus untuk pemasaran sedang dirancang menciptakan embrio peternak kambing PE di wilayah Kabupaten Bangkalan pada pondok-pondok pesantren, jika perlu dijadikan plasma peternak kambing PE yang bersumber dari bibit milik Bapak Solikan sebagai inti.

Menjadi peternak suskses tidaklah mudah, diperlukan ketekunan, kesabaran dan keyakinan serta keikhlasan dalam merawat dan membesarkan ternaknya. Selain masalah psikologis peternak, faktor produksi seperti bibit, pakan dan kesehatan sangat penting. Bibit kambing yang unggul akan memberikan turunan yang unggul pula, memiliki ketahanan tubuh terhadap penyakit serta fisik yang kuat.

Pakan sangat penting terutama bagi kambing yang dikandangkan dibandingkan dengan kambing yang digembalakan. Bagi ternak yang dikandangkan akan sangat tergantung pada peternak dalam memberikan pakan, pemahaman yang dimiliki peternak terhadap kualitas pakan dapat memberi efek langsung kepada kambing yang dipelihara.

Sebagaimana yang dilakukan oleh peternak mitra, bahwa pakan yang diberikan selama ini memiliki kandungan nutrisi kurang baik. Keadaan fisik kambing terlihat gemuk, namun sebenarnya adalah gemuk semu, artinya tidak bertahan lama. Bahan pakan berupa ampas tahu bersifat basah, ditambah dengan bonggol dan kulit ketela pohon (meski sudah direndam 1 hari), masih mengandung unsur HCN atau asam sianida yang mengakibatkan kambing sering kembung dan mencret. Oleh karena itu pembuatan pakan formula yang diusulkan tidak menggunakan bahan ampas tahu dan bonggol/kulit ketela pohon. Pakan hijauan/ jerami yang dicampur dengan ampas tahu dan difermentasi selama 4 jam tidak efektif karena tidak terjadi pemecahan ikatan lignoselulosa menjadi selulosa yang lebih sederhana agar mudah dicerna oleh ternak ruminansia. Sedangkan fermentasi hijauan idealnya membutuhkan waktu lebih lama, yaitu 3-4 hari agar dapat menghasilkan selulosa yang mudah dicerna oleh kambing. Ampas tahu juga menyebabkan fisik pakan lebih basah dan mudah busuk.

Dari segi reproduksi, yang harus dihindari adalah terjadinya inbreeding pada perkawinan antar ternak. Manajemen populasi seharusnya dapat menekan terjadinya inbreeding (perkawinan satu gen) sehingga akan menghasilkan turunan yang rentan dengan kematian atau cacat. Peternak mitra tidak memiliki catatan populasi, tetapi untuk sementara hafal mana induk, mana F1 dan mana F2nya. Tetapi kenyataanya dari tingkat kematian anak hampir mencapai $60 \%$.
Dari aspek penanganan susu, seharusnya seekor kambing dapat mengahasilkan susu antara 0.5-1 liter per hari selama 3-5 bulan masa laktasi. Harga susu kambing sekitar Rp. 15.000 s/d Rp. 20.000,- per liter. Manfaat susu kambing yang tinggi bagi penderita sakit maag dan pernafasan (bronchitis, TBC) bahkan untuk penderita kanker. Dengan tidak ditanganinya susu yang dihasilkan dari kambing peternak mitra, maka peluang untuk mendapatkan penghasilan tambahan hilang begitu saja. Oleh karena itu, solusi yang digunakan adalah kunjungan studi banding dan selanjutnya magang pada proses pengolahan susu kambing di Singosari Malang.

\section{SIMPULAN DAN REKOMENDASI}

Berdasarkan uraian kegiatan Pengabdian pada Masyarakat pada peternak Kambing PE di Morowudi, Kecamatan Cerme, Gresik dapat disimpulkan sebagai berikut:

a. Hasil pakan alternatif probiotik pola fermentasi dengan media biakan MC4 terbukti lebih murah karena menghilangkan beberapa bahan seperti ampas tahu dan bonggol kulit ketela pohon yang harganya cukup mahal dan penanganannya rumit.

b. Pakan formula baru yang diterapkan terbukti disukai dan memiliki nilai palatabilitas yang tinggi.

c. Pakan formula yang dibuat sebelumnya memiliki kandungan nutrisi yang rendah dan kurang memenuhi kebutuhan, harus segera disajikan dan dikonsumsi oleh ternak agar tidak busuk. Sedangkan pakan formula baru mengandung nilai nutrisi yang cukup baik.

Berdasarkan kesimpulan yang telah dikemukakan maka direkomendasikan untuk menggunakan pakan formula hasil fermentasi dengan MC4 bila ditinjau dari segi teknik, kesehatan dan ekonomis karena mempunyai nilai gizi lebih baik, dapat meningkatkan palatabilitas ternak, mudah pembuatannya dan harganya lebih rendah dibandingkan penggunaan EM4. Untuk meningkatkan pendapatan, diharapkan peternak mitra segera mengambil langkah penanganan produksi susu secara benar.

\section{UCAPAN TERIMA KASIH}

Penulis mengucapkan terima kasih kepada Bapak Solikan selaku peternak mitra yang berdomisili di Desa Morowudi, Kecamatan Cerme, Kabupaten Gresik atas kerjasamanya dalam pelaksanaan kegiatan pengabdian masyarakat ini. Penulis juga mengucapkan terima kasih kepada Rektor Universitas 17 Agustus 1945 Surabaya 
melalui LPPM Untag Surabaya yang telah membiayai kegiatan Pelaksanaan Program Kemitraan Masyarakat bagi dosen pada Tahun Anggaran 2019 dengan Kontrak Penugasan No. 488.19/ST/003/ LPPM/Abdimas/VI/2019.

\section{DAFTAR PUSTAKA}

AOAC. 1975. Official Methods of Analysis. 12th edition. Association of Official Analytical Chemists. Washington, D.C.

Arroyo D. 2000. Gasification of Lignin from Rice Straw. University of Puerto Rico. Mayaguez Campus National Renewable Energy Laboratory Golden, Colorado. 80401.

Elizalde JC, JD Cremin Jr, DB Faulkner, and NR Merchen. 1998. Performance and digestion by steers grazing tall fescue and suplemented with energy and protein. J. Anim. Sci.76: 1691-1701

Eun JS, KA Beauchemin, SH Hong, and MW Bauer. 2006. Exogenous enzymes added to rice straw: Effect on in vitro fermentation characteristic and degradability. J. Anim. Sci. and Tech. 131: 86-101.
Eun JS. 2007. Assessment of The Efficacy of Varying Experimental Exogenous Fibrolitik Enzymes Using in Vitro Fermentation Characteristics. J. Anim. Sci. 132: 298-315.

Farrel RL, JJG Molina, and JED Guierrez. 2006. Isolation and Use of Decay Fungi. US Patent \& Trade Mark Office. No. 0060246570. Goering HK and PJ Van Soest. 1970. Forage Fiber Analysis, Agricultur Hand Book No. 379, Agricultural Research Service, USDA, Washington DC.

Hatakka A. 2000. Biodegration of Lignin. University of Helsinki, Viikki Biocenter, Department of Applied Chemistry dan Microbiology. Helsinki.

Orskov ER, Hovell and Mould F. 1982. The Use of The Nylon Bag Technique for The Evalution of Feedstuff. J. Trop. Animal Prod. 5: 195 - 213.

Prihartini I, Soebarinoto, S Chuzaemi dan M Winugroho. 2007. Studi Potensi Bakteri Lignolitik Dalam Mendegradasi Lignin dan Organochlorin pada Peningkatan Nilai Nutrisi Jerami Padi Sebagai Pakan Ternak Ruminansia. Disertasi. Pascasarjana Universitas Brawijaya. Malang. 